\title{
COMMON NAMES OF SOUTH ASIAN THERAPHOSID SPIDERS (ARANEAE: THERAPHOSIDAE)
}

\author{
Sanjay Molur ${ }^{1,2}$, and Manju Siliwal ${ }^{2,3}$ \\ ${ }^{1}$ Zoo Outreach Organisation, ${ }^{2}$ Wildlife Information \& Liaison Development Society, \\ 29-1, Bharathi Colony, Peelamedu, Coimbatore, Tamil Nadu 641004, India \\ Email: ${ }^{1}$ herpinvert@vsnl.com, ${ }^{3}$ manjusiliwal@rediffmail.com
}

\begin{abstract}
Some spiders of the Family Theraphosidae have been in the limelight for a few years now due to a growing interest in their trade. Trade names have been given, albeit inconsistently and not all species have common names. This paper provides standardized common names for the 62 described species of South Asian theraphosid spiders along with information on their distribution as known from literature.

\section{KEYWORDS}

Common names, distribution, mygalomorphs, South Asia, tarantula, theraphosid spiders
\end{abstract}

The suborder Orthognatha consists of some of the most primitive spiders of the world, mainly attributable to the horizontally directed chelicerae, simple epigyne structure and two pairs of booklungs (Kaston, 1980). Suborder Orthognatha and its infraorder Mygalomorphae (Raven, 1985) is represented by 15 families world wide, out of which eight families are found in South Asia (Platnick, 2004). Family Theraphosidae is a popular group due to the vivid colouration and large size of some of its members. Globally, the family Theraphosidae is represented by over 800 species in 13 subfamilies (Hüber et al., 1996), out of which 62 species in five subfamilies and 11 genera have been described from South Asia. Referring to various sources, we recognize the following five subfamilies as occurring in India, namely, Ischnocolinae, Selenocosmiinae, Poecilotheriinae, Thrigmopoeinae and Selenogyrinae.

Pocock (1900b), Raven (1985), Smith et al. (2001) and Smith and Kirk (2001) consider the genus Poecilotheria to be in the subfamily Selenocosmiinae based on the stridulatory organ structure. However, we follow the classification given by Hüber et al. (1996), who treats the genus Poecilotheria separately in the subfamily Poecilotheriinae. Despite having similar stridulatory organ structure similar to the members of the family Selenocosmiinae, this genus is distinct in arboreal living habits, having comparatively thinner and longer legs, preferring wooded areas and tree holes, and having unique behaviours. Similarly, the genus Annandaliella is considered to be in the subfamily Selenogyrinae by Hüber et al. (1996) instead of in the subfamily Selenocosmiinae as considered by Raven (1985) and Smith \& Kirk (2001).

Linnaeus in 1758 first described the theraphosid Avicularia avicularia although Madam Maria Merian had illustrated in 1700 the first South Asian theraphosid in Ceylon [= Sri Lanka]. The binomial, Mygale fasciata, was given to this illustration by Latreille (1804). Later Koch (1850) named this animal Scurria fasciata by Koch (1850). However, the genus name Scurria was already preoccupied by a mollusc and hence in 1885, Simon proposed Poecilotheria as a replacement name (Pocock, 1899). For 91 years Poecilotheria fasciata was the only member of this genus. After this gap, Pocock (1895) described P. subfusca from Sri Lanka and P. striata from India (making this the first species of this genus described from India).

Later, Walckenaer in 1837 described Mygale javanensis from Java, which is now Selenocosmia javanensis after Ausserer (1871) erected the new genus. Pocock in 1900 reported Selenocosmia javanensis from Nicobar Island. However, this needs more detailed studies since the insular population could be a different taxon.

The first Theraphosid to be described from India was Chilobrachys stridulans by Wood-Mason in 1877 as Mygale stridulans from Sibsagar in Assam. In 1900, Pocock included Mygale stridulans under the genus Chilobrachys, which was described by Karsch (1891) based on Chilobrachys nitelinus from Sri Lanka. Its occurrence was confirmed with additions of new localities in Assam and West Bengal by Hirst (1909).

To date forty-nine species of theraphosids are endemic to India (out of which one is endemic to the Andaman \& Nicobar Islands), nine species are endemic to Sri Lanka and one species is endemic to Nepal (Table 1). The genus Poecilotheria is endemic to South Asia, so far known only from India and Sri Lanka. Haplocosmia is a monotypic genus from Nepal. Three genera endemic to India are Annandaliella Hirst, 1909, Haploclastus Simon, 1892 and Thrigmopoeus Pocock, 1899, although further revisions in systematics could change these statistics. Two new species were named in an informal publication by Smith and Kirk (2001) - one from the South Andaman Island and the other from near Ponmudi, Kerala. They have not been taken into consideration here as the booklet distributed during the Eastern Hemisphere Tarantula workshop in Parambikulam in September 2001 was not formally published and therefore does not meet the standards for recognizing a new species.

The checklist of Indian spiders by Tikader (1987) listed 50 species of theraphosids from India, many of which have been either synonymised or transferred. This checklist of South Asian theraphosids is the most updated list primarily based on Platnick (2004) and Siliwal et al. (in prep).

The first taxonomists who described South Asian theraphosids included foreigners/westerners such as Latreille (1804), Walckenaer (1837), Wood-Mason (1877), Simon (1884, 1891, 
1892) and Pocock $(1895,1899,1900 a, b)$. R.I. Pocock has contributed much to the knowledge of theraphosids in the region with 29 new descriptions out of 62 species (Pocock 1895, $1899,1900 a, b)$. All the descriptions were based on the specimens deposited at the British Museum. The first arachnologist to study Indian theraphosids in the field was Gravely $(1915,1935)$, the then Superintendent of the Government Museum in Madras (Chennai). Thereafter, some Indian arachnologists contributed to this field like Dyal (1935), Tikader (1977) and Barman (1978). After this there was a gap of 17 years, in which no new theraphosid descriptions were formally reported from South Asia. There have been several references in various popular and semi-scientific papers on newer species of theraphosids by pet traders/taxonomists in Europe, with some claims of new hybrid species in captivity. Theraphosids became popular in the western countries in the pet trade in the early 1990s and since then a few traders from Europe started taking interest in South Asian theraphosid taxonomy. Subsequently, taxonomists and parataxonomists associated with traders took interest in describing newer species of this group since 1996.

Information on distribution of theraphosid species in this paper is from a variety of sources ranging from type localities to additional information from published sources and our own compilation of locality information through the questionnaire and field survey conducted in the last four years. The names of localities have been retained as such from the original papers and current names are used in the cases of our records and newer publications.

\section{Common names for South Asian theraphosids}

Theraphosids are commonly called tarantulas by the Americans, which has its origin in Italy, where lycosid spiders (of suborder Labidognatha) were referred to by the name. Although the term is a misnomer for the group of hairy theraphosids, the usage is almost universal, thanks not only to popular and scientific literature from the United States, but also to many references to the group by hobbyists from America and Europe who have established 'Tarantula Societies', childrens' books, and also the infamous movies produced by Hollywood. Initially the term tarantula was used to refer to the group of theraphosid spiders of South and Central Americas, popular in pet trade as bird-eating spiders. The addition of similar spiders from other parts of the world has resulted in all theraphosid spiders in the pet trade being referred to as tarantulas. The Indian theraphosids were even referred to as Eastern Hemisphere tarantulas. South Asians are not very familiar with the term and think tarantulas do not occur in the region. They are correct, in a sense, as the term is more applicable to the Old World wolf spiders. In this paper, we have tried to stay away from the term tarantula and provide common names for every theraphosid species described until date from this region.

The recent controversy of 'tarantulas' killing people in West Bengal is a good example of the lack of knowledge of spiders in general and theraphosids in particular. The controversy ranged from whether tarantulas occur in India or not to whether they could be considered a deadly group of spiders that actively chase and kill humans, clearly a misconception. This overview is to establish some basic common names with an intention to increase awareness about the taxonomy and biology of these spiders in the region.

Common names have been provided for some of the popular Indian and Sri Lankan theraphosids in trade, but these names are used randomly with many variations between countries and traders. Further, since not all South Asian theraphosid species have common names the current list presented here is meant to help establish standardized names. This would also help legislators in the South Asian countries easily determine the groups/genera/species to be included in wildlife legislation for conservation.

\section{Rationale of common names for the species / groups}

The subfamily Ischnocolinae has confirmed members of the genera Plesiophrictus, which are very small hairy spiders usually found in small burrows in many areas of southern India and also in northeastern India. The other genus reported by Tikader (1977) with two species, Iscnocolous decoratus and I. khasiensis seem to be wrongly identified as the diagrams indicate otherwise. However, since all the spiders in this subfamily are small compared to other theraphosids, they have been called 'Small hairy burrowers'.

The genus Poecilotheria needs separate treatment rather than combining it with other similar species of the subfamily Selenocosmiinae. This group of arboreal spiders has a unique behaviour from which the name is derived. When the males are disturbed on a tree or on a wall, they tend to jump either to the neighbouring tree, or more often just sail down like a leaf to the ground, after which their excellent camouflaging colours make them nearly invisible. We have observed these spiders to 'parachute' down in the wild, hence we propose the name 'Parachute spiders'.

The genus Annandaliella of the subfamily Selenogyrinae are not active burrowers, are very small, and are restricted to India. They are usually seen occupying crevices under rocks and roots, hence we call them 'Tiny Indian rock spiders'.

The subfamily Selenocosmiinae translates roughly to 'ornamented' spiders, hence the name is given to Selenocosmia genus of the group. However, the genus Chilobrachys is easily identifiable by its chevron markings and so the ground spiders under this group are called 'Striated Burrowing Spiders'. Similarly, the other genera, Haplocosmia, Phlogeillus and Lyrognathus are called 'Bright burrowing spiders'.

The Thrigmopoeinae group has two main genera, Thrigmopoeus and Haploclastus, although there is much speculation about unifying all the spiders under the genus Thrigmopoeus. These spiders are some of the bigger ground burrowers, and are restricted to the South Asian mainland, hence we call them 'Large Indian burrowing spiders'

Further, we have referred to individual spider species either by 
Table 1. Suggested common names for South Asian theraphosid spiders

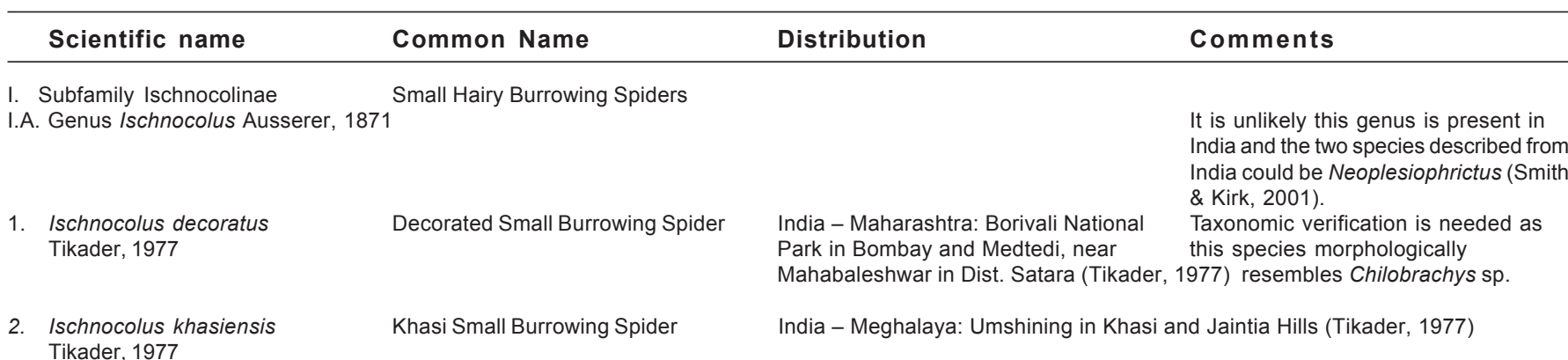

I.B. Genus Plesiophrictus Pocock, 1899

3. Plesiophrictus bhori

Parambikulam Small Burrowing Spider India - Parambikulam, Cochin State (Gravely, 1915)

Gravely, 1915

Anamalai Small Burrowing Spider

India - Panchgani, Satara Dist. (Gravely, 1935); Parambikulam in Cochin State (Smith \& Kirk, 2001)

Gravely, 1935

Yercaud Small Burrower

India - Yercaud in Shevaroy Hills; Madras Presidency (Pocock, 1899; Pocock, 1900b)

Pocock, 1899

India - Madura (Pocock, 1900b)

Known only from the type locality.

6. Plesiophrictus fabrei (Simon, 1892) Madurai Small Burrower

India - Pondicherry (Pocock, 1900b)

Known only from the type locality.

8. Plesiophrictus madraspatanus Madras Small Burrower Gravely, 1935

India - Madras city; Chingleput Dist.: Velacheri, Nagalapuram Hill and Kambakkam Hill (Gravely, 1935)

9. Plesiophrictus mahabaleshwari Tikader, 1977

Mahabaleshwar Small Burrowing Spider India- Maharashtra: Mahabaleshwar in Satara, Dist. (Tikader, 1977)

10. Plesiophrictus meghalayaensis Meghalaya Small Burrowing Spider Tikader, 1977 India - Meghalaya: Nongrim Hills in Known only from the type locality. Shillong (Tikader, 1977)

11. Plesiophrictus millardi Pocock, 1899 Matheran Small Burrowing Spider

12. Plesiophrictus milleti (Pocock, 1900) Nasik Small Burrowing Spider

13. Plesiophrictus raja Gravely, 1915 Cochin Small Burrowing Spider

India - Matheran; Uran in Mumbai region (Pocock, 1899)

India - Nasik; Eastern Poona; Jauli in Satara (Pocock, 1900b)

India - Kavalai in Cochin State Forest Known only from the type locality. Tramway (Gravely, 1915)

14. Plesiophrictus satarensis Satara Small Burrowing Spider Gravely, 1915

India - Bombay Presidency: Medha in Yenna Valley, Umbri, Taloshi, Helvak and Kembsa in Koyna Valley of Satara Dist. (Gravely, 1915)

15. Plesiophrictus sericeus Pune Small Burrowing Spider Pocock, 1900

India - Eastern parts of Poona Dist. Known only from the type locality. (Pocock, 1900b)

16. Plesiophrictus tenuipes Kandy Small Burrowing Spider Pocock, 1899

Sri Lanka - Kandy (Pocock, 1899; Known only from the type locality. Pocock, 1900b)

II. Subfamily: Poecilotheriinae Indian and Sri Lankan Parachute Spiders

II.A.Genus Poecilotheria Simon, 1885 Parachute Spiders

17. Poecilotheria fasciata Banded Parachute Spider (Latreille, 1804)

India and Sri Lanka Endemic to South Asia.

Sri Lanka - Trincomali, Kandy, Punduloya (Pocock, 1900a,b) Ambakele, Andigama, Anuradhapura, Wilpattu, Habarana (Smith \& Kirk, 2001)

18. Poecilotheria formosa Beautiful or Fine Parachute Spider Pocock, 1899

India - Mullapuram and Kadiampatti, in Salem Dist. (Pocock, 1900a,b); Renigunta station (Smith \& Kirk, 2001)

19. Poecilotheria hanumavilasumica Rameshwaram Parachute Spider Smith, 2004

20. Poecilotheria metallica Pocock, 1899

Peacock Parachute Spider India - Pamben Island and Mandapam (Smith, 2004)

21. Poecilotheria miranda Pocock, 1900 Wonderful or Red Parachute Spider India - Near Gooty (Pocock, 1900a,b) Known only from the type locality. India - Chota Nagpur (Pocock, 1900b): Kharagpur Hills and Near Chaibassa in Singbhum Dist. (Gravely, 1915)

22. Poecilotheria ornata Pocock, 1899 Ornate Parachute Spider Sri Lanka - Ratnapura (Pocock, 1900a,b), Nuwara Eliya, Labungama, Deryaniyagala, Sinharaja (Smith \& Kirk, 2001)

Sri Lanka - Hambantota Dist.

23. Poecilotheria pederseni Kirk, 2001 Hambantota Parachute Spider

\section{(Smith \& Kirk, 2001)}




\begin{tabular}{llll}
\hline Scientific name & Common Name & Distribution & Comments \\
\hline $\begin{array}{l}\text { 24. Poecilotheria pococki } \\
\text { Charpentier, 1996 }\end{array}$ & Pocock's Parachute Spider & Sri Lanka & $\begin{array}{l}\text { Due to unavailability of original } \\
\text { reference, we are unable to give the } \\
\text { exact locality. }\end{array}$
\end{tabular}

25. Poecilotheria regalis Pocock, 1899 Regal or King Parachute Spider

26. Poecilotheria rufilata Pocock, 1899 Reddish or Rufus Parachute Spider

27. Poecilotheria smithi Kirk, $1996 \quad$ Kandy Parachute Spider

28. Poecilotheria striata Pocock, 1895 Striped or Striated Parachute Spider

29. Poecilotheria subfusca Pocock, 1895 Brown Parachute Spider

30. Poecilotheria uniformis Strand, 1913 Uniform Parachute Spider

III. Subfamily Selenogyrinae

III.A.Genus Annandaliella Hirst, 1909 Tiny Indian Rock Spider

31. Annandaliella pectinifera Coimbatore Rock Spider

Gravely, 1935

32. Annandaliella travancorica Travancore Rock Spider Hirst, 1909

IV. Subfamily Selenocosmiinae

IV.A.Genus Chilobrachys Karsch, 1891 Striated Burrowing Spider

33. Chilobrachys andersoni (Pocock, 1895)

Anderson's Striated Burrowing Spider India, Myanmar, Malaysia

34. Chilobrachys assamensis Hirst, 1909 Assam Striated Burrowing Spider

35. Chilobrachys femoralis Pocock, 1900 Nasik Striated Burrowing Spider

36. Chilobrachys fimbriatus Pocock, 1899

Fimbriated Striated Burrowing Spider

37. Chilobrachys flavopilosus (Simon, 1884)

38. Chilobrachys fumosus (Pocock, 1895)

39. Chilobrachys hardwicki (Pocock, 1895)

Myanmar or Yellow Striated Burrowing Spider India, Myanmar

India - Sibsagar (Hirst, 1909)

India - Nasik (Pocock, 1900b)

India - Khandalla (Pocock, 1899); Hoshali in Shimoga Dist., Mysore; Jaoli in Satara (Pocock, 1900b); Castle Rockin North Kanara Dist; Panchgani in Satara Dist. (Gravely, 1935) Karnataka; Kallar, Ponmudi, Peppara Dam, Agastyavalam Reserve (Smith \& Kirk,

Sri Lanka - Haragama, Kandy (Smith \& Kirk, 2001)

India - Penang (Pocock, 1900a; Mysore, Trivandrum in Travancore (Pocock, 1900b); Rameshwaram Island (Gravely, 1915)

(Pocock, 1900a): Kandy (Pocock, 1900b); (Smith \& Kirk, 2001)

Sri Lanka

Due to unavailability of original reference, we are unable to give the exact locality.

Endemic to India.

Known only from the type locality.

India - Kulattupuzha in Travancore, Trichur in Cochin, Cochin State Forest Tramway (Gravely, 1915) reference, we are unable to give the exact locality.

Known only from the type locality.

Known only from the type locality. reference, we are unable to give the exact locality.

Provinces; Bilaspur in Central provinces; Burdwan (Pocock, 1900b); Bihar: Dharhara in Monghyr Dist. Nagpur; Gmatia in Birbhum Dist. and Murshidabad in Bengal (Gravely, 1915); Hazaribagh in Bihar (Gravely, 1935)

40. Chilobrachys nitelinus Karsch, 1891 Sri Lankan Striated Burrowing Spider Sri Lanka - Punduloya and Dikoya (Pocock, 1900b)

41. Chilobrachys stridulans (Wood-Mason, 1877)

42. Chilobrachys thorelli Pocock, 1900 Sadiya Striated Burrowing Spider

IV.B.Genus Haplocosmia Schmidt \& von Wirth, 1996

43. Haplocosmia nepalensis Schmidt \& von Wirth, 1996

Nepal Bright Burrowing Spider

V.C.Genus Lyrognathus Pocock, 1895

44. Lyrognathus crotalus Pocock, 1895
Stridulated Striated Burrowing Spider Gravely, 1915) and Sibsagar (Pocock, 1900b; Gravely, 1915); Punkabari in Darjeeling Hills (Hirst, 1909; Gravely, 1915)

India - Sadiya (Pocock, 1900b)

Known only from the type locality.

Endemic to Nepal.

Nepal - Kathmandu (Smith \& Kirk, 2001) Known only from the type locality.
Northern Indian Bright Burrowing Spide India - Northern India (Pocock, 1900b)
Known only from the type locality. Exact locality is not known. 


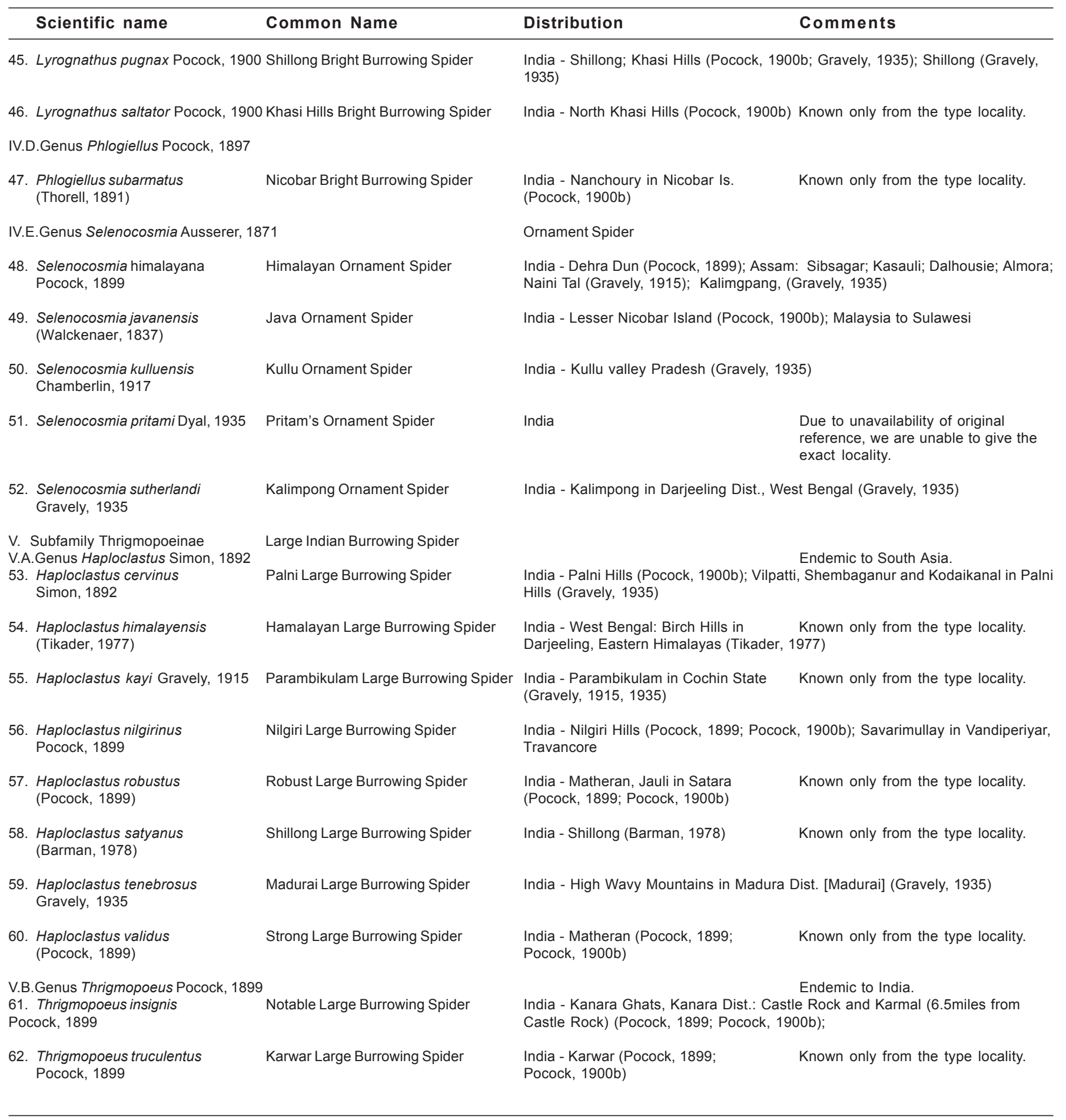


their characters (if denoted in the Latin name, or if known from morphology), by place names (usually type localities, or in cases with a broader distribution, by the region's name), or very rarely after the person's name after which the species has been described.

\section{REFERENCES}

Ausserer, A. (1871). Beiträge zur Kenntniss der Arachniden-Familie der Territelariae Thorell (Mygalidae Autor). Verh. zool.-bot. Ges. Wein 21: 117-224.*

Barman, M. (1978). A new mygalomorph spider of the genus Phlogiodes from Khasi-Jaintia Hills, India (Araneae: Theraphosidae). Journal of the Bombay Natural History Society 75: 168-169.

Charpentier, P. (1996). A new species of Poecilotheria from Sri Lanka: Poecilotheria pococki, sp. n. Exothermae Mag. 1: 21-33.*

Dyal, S. (1935). Spiders of Lahore. Bulletin of the Department of Zoology Panjab University 1: 117-252.*

Gravely, F.H. (1915). Notes on Indian mygalomorph spiders. Records of the Indian Museum Calcutta 11: 257-287.

Gravely, F.H. (1935). Notes on Indian mygalomorph spiders. II. Records of the Indian Museum Calcutta 37: 69-84.

Hirst, A.S. (1909). On some new or little-known mygalomorph spiders from the Oriental Region and Australasia. Records of the Indian Museum Calcutta 3(4:30): 383-390.

Hüber, S., R. Samm and G. Schmidt (1996). Theraphosidae der Welt. Arachnologisches Magazin November: 1-65. *

Karsch, E. (1891). Arachniden von Ceylon und von Minikoy gesammelt von den Herren Doctoren P. und F. Sarasin. Berl. ent. Zeitschr. 36: $267-$ 310 .*

Kaston, B.J. (1980). How To Know The Spiders. $3^{\text {rd }}$ edition, $2^{\text {nd }}$ print. The Pictured Key Nature Series. Wm. C. Brown Company, Iowa, 272pp. Kirk, P.J. (1996). A new species of Poecilotheria (Araneae: Theraphosidae) from Sri Lanka. British Tarantula Society Journal 12 20-30.

Kirk, P.J. (2001). A new species of Poecilotheria (Araneae: Theraphosidae) from Sri Lanka. British Tarantula Society Journal 16 : 77-88.

Koch, C.L. (1850). Übersicht des Arachnidensystems. Nürnberg, Heft 5, pp. 1-77.*

Latreille, P.A. (1804). Tableau methodique des Insectes. Nouv. Dict d'Hist. Nat., Paris 24: 129-295."

Linnaeus, C. (1758). Systema naturae per regna tria naturae, secundum classes, ordines, genera, species cum characteribus differentiis, synonymis, locis. Editio decima, reformata. Holmiae, 821 pp. (Araneae, pp. 619-624).*

Platnick, N.I. (2004). The world spider catalog, version 4.5. American Museum of Natural History, online at http://research.amnh.org/ entomology/spiders/catalog/index.html

Pocock, R.I. (1895). On a new and natural grouping of some of the Oriental genera of Mygalomorphae, with descriptions of new genera and species. Annals and Magazine of Natural History (6) 15: 165-184.*

Pocock, R.I. (1899). Diagnoses of some new Indian Arachnida. Journal of the Bombay Natural History Society 12: 744-753.

Pocock, R.I. (1900a). Great Indian spiders. The genus Poecilotheria: its habits, history and species. Journal of the Bombay Natural History Society 13: 121-133.

Pocock, R.I. (1900b). The fauna of British India, including Ceylon and Burma. Arachnida. Taylor \& Francis, London, 279pp.

Raven, R.J. (1985). The spider infraorder Mygalomorphae (Araneae): Cladistics and systematics. Bulletin of American Museum of Natural History 182: 1-180. *

Siliwal M., S. Molur and B.K. Biswas (in prep). Updated checklist of Indian Spiders (Arachnida: Araneae).

Simon, E. (1884). Arachnides recueillis en Birmanie par M. le chevalier J. B. Comotto et appartenant au Musée civique d'histoire naturelle de Gènes. Ann. Mus. civ. stor. nat. Genova 20: 325-372.*

Simon, E. (1885). Matériaux pour servir à la faune arachnologiques de
l'Asie méridionale. I. Arachnides recuellis à Wagra-Karoor près Gundacul, district de Bellary par M. M. Chaper. II. Arachnides recuellis à Ramnad, district de Madura par M. l'abbé Fabre. Bulletin of the Society of Zoology France 10: 1-39.*

Simon, E. (1891). Etudes arachnologiques. 23e Mémoire. XXXVIII. Descriptions d'espèces et de genres nouveaux de la famille des Aviculariidae. Ann. Soc. ent. Fr. 60: 300-312.*

Simon, E. (1892). Histoire naturelle des araignées. Paris, 1: 1-256.* Smith, A.M. (2004). A new species of the Arboreal Theraphosid, Genus Poecilotheria, from Southern India (Araneae, Mygalomorphae, Theraphosidae) with notes on its Conservation Status. Journal of the British Tarantula society 19(2): 33-64.

Smith, A.M. and P. Kirk (2001). A field Guide on the theraphosid spiders of Indian and Sri Lanka particularly the Genus Poecilotheria. (unpublished).

Smith, A.M., P. Carpenter, J.-P. Lamoureux (2001). Study notes on an interesting example of habitat adaptation in the Sri Lankan theraphosid spider Poecilotheria fasciata. Journal of the British Tarantula Society 16(2): 46-59.

Tikader, B.K. (1977). Studies on some mygalomorph spiders of the families Ctenizidae and Theraphosidae from India. Journal of the Bombay Natural History Society 74: 306-319.

Tikader, B.K. (1987). Handbook Indian Spiders. Zoological Survey of India, Calcutta, $251 \mathrm{pp}$.

Walckenaer, C.A. (1837). Mémoire sur une nouvelle espèce de Mygale, sur les théraphoses et les divers genres dont se compose cette tribu d'Aranéides. Ann. Soc. ent. Fr. 4: 637-651.*

Wood-Mason, J. (1877). Note on Mygale stridulans. Transactions of the Entomological Society of London 1877: 281-282.*

* Original not referred.

\section{ACKNowledgement}

We are grateful to the following individuals and institutions who have supported and continue to support the Indian theraphosid distribution and status project morally and financially: Ms. Sally Walker, Zoo Outreach Organisation; Conservation Treaty Support Fund; Whitley Award; Rufford Small Grants; Chicago Zoological Society Endangered Species Support Fund; Dr. B.K. Biswas, Zoological Survey of India; Dr. K. Ganeshkumar, Tamil Nadu Agricultural University, Mettupalayam; Dr. B.A. Daniel, Dr. C. Srinivasulu; Mr. P.O. Nameer; Mr. Vivek GourBroome; Mr. Sanjay Thakur; Dr. Sukhdev, Chief Wildlife Warden, Tamil Nadu Forest Department; Dr. S.S. Bist, Director, Project Elephant, Ministry of Enivironment \& Forests, Government of India; Mr. Dave Ferguson and Mr. Kurt Johnson of the United States Fish and Wildlife Service; Mr. Paul Pearce-Kelly, London Zoo; Dr. Paula Cushing for commenting on the draft; to the three reviewers for their constructive comments

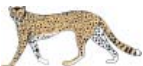

